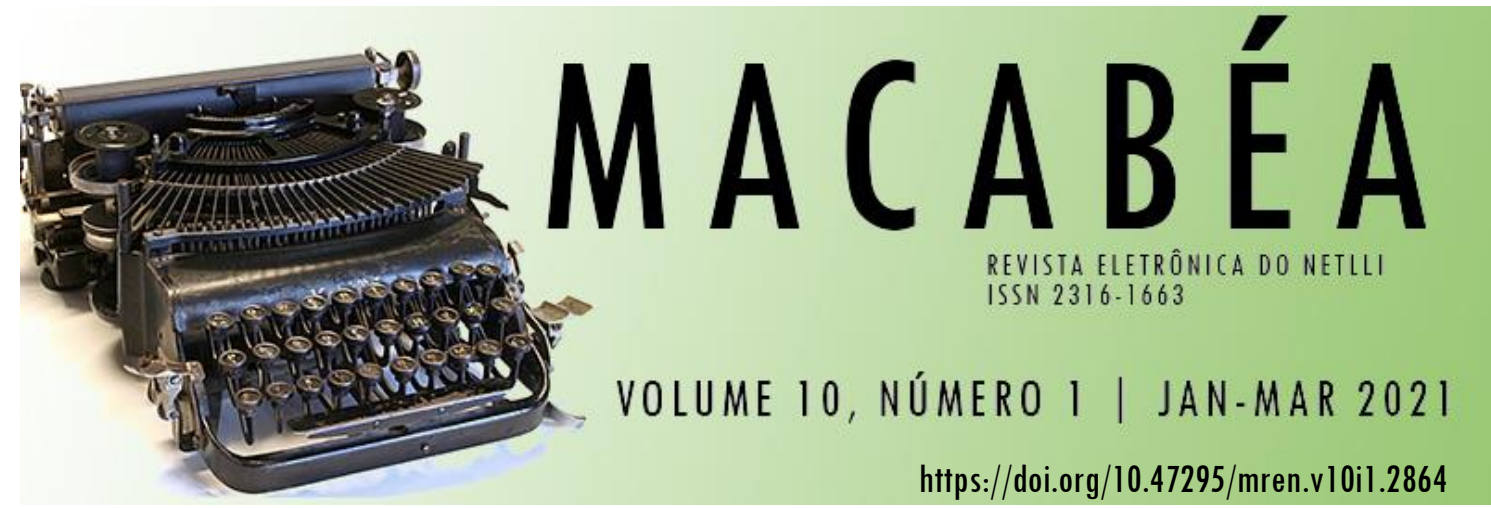

\title{
LOST IN TRANSLATION? FROM O ESCRAVO TO A ILHA DOS ESCRAVOS
}

\section{LOST IN TRANSLATION'? DE O ESCRAVOA ILHA DOS \\ ESCRAVOS}

FRANCISCO TOPA

\author{
RESUMO | INDEXAÇÃO | TEXTO | REFERÊNCIAS | CITAR ESTE ARTIGO | 0 AUTOR \\ RECEBIDO EM 03/09/2020 • APROVADO EM 23/11/2020
}

\begin{abstract}
:
The adaptation of literary works to film raises a complex series of theoretical and practical questions which have long been discussed. These, however, may become more complex should the distance between the book and the film be even wider, as when there occurs a transition from colonial to post-colonial times, and when the director chooses a sharp transformation of the plot and outlines of the characters, giving the film a different slant from the one that characterized the novel. This paper discusses the case of Francisco Manso, a well-known Portuguese director and producer, whose work includes the film adaptation of literary texts from Cape Verde, such as $\mathbf{0}$ testamento do Senhor Nepumoceno da Silva Araújo (1997), A ilha dos escravos (2008) and Os dois irmãos (2018). I shall focus on the second of these films, arguing that this adaptation is not a mistranslation of $\mathbf{O}$ Escravo, a pioneer novel by José Evaristo d'Almeida published in 1856.
\end{abstract}

\section{Resumo:}

A adaptação de obras literárias para o cinema coloca uma série complexa de questões teóricas e práticas que vêm sendo discutidas de há muito. 0 problema é mais grave quando a distância do livro ao filme consiste na passagem da época colonial para a pós-colonial e o realizador opta por uma transformação abrupta da trama e contornos das personagens, dando ao filme uma orientação diferente daquela que caracterizava o romance. Este artigo aborda 0 caso de Francisco Manso, conhecido realizador e produtor português, cuja filmografia inclui a adaptação de obras literárias cabo-verdianas: é o caso de 0 testamento do Senhor Nepumoceno da Silva Araújo (1997), A ilha dos escravos (2008) e Os dois irmãos (2018). 0 artigo foca 0 segundo filme, 
sustentando que não se trata de uma tradução incorreta de $\mathbf{0}$ Escravo, romance pioneiro de José Evaristo d'Almeida publicado em 1856.

\section{Entradas para indexação}

KEY WORDS: Cape Verde; literature; film; José Evaristo d'Almeida; Francisco Manso.

PALAVRAS-CHAVE: Cabo Verde; literatura; filme; José Evaristo d'Almeida; Francisco Manso.

\section{Texto integral}

As is often emphasized, the connections between literature and cinema are almost as old as the motion picture industry, principally through adaptation of literary texts (usually novels) to film. The reasons for this are known and two of them particularly noteworthy: first, the desire to reread a literary work and to reach out other, potentially wider, audiences; second, the sharing between the two arts of some of the narrative codes they make use of. However, the result is often disappointing, especially for an audience who has read and admired the book before its adaptation to film.

In most cases the problem stems from the exercise of comparison and from not taking into account the limitations of each of the arts. Compared to the literary text, cinema seems to operate by reduction, counterposing a more or less precise and concrete image to idealization. In fact, what happens is more than just this: it is not a mere transposition, contrary to what the prefix ad- (in adaptation) suggests; it is a new text, the result of interpretation and creation, which, contrary to what may appear at a first glance, are original, even if the ties with the literary hypotext are visible.

The above can serve as an introduction to the adaptation of the novel $\mathbf{0}$ escravo, published in 1856 by José Evaristo d'Almeida, in Francisco Manso's film A ilha dos escravos, released in 2008. A little more than a century and a half separates the two works, which are connected - in addition to the most obvious reason - by a particularity: both present, mainly because of the themes involved, features which are innovative for their time and for their area of circulation; and both were, for reasons not easily discernible, received with cold indifference.

Before moving on to a comparative study, I should briefly present the data. Let us begin with the author of the novel, José Evaristo d'Almeida, about whom we know very little, in spite of the studies that have been published since the reissue of the text by Manuel Ferreira in 1989 (Almeida, 1989). As I have demonstrated in an article published some years ago (Topa, 2013), we can deduce from a poem of 1852 (Epístola $a^{* * *}$ ) that the author of the first Cape Verdean novel probably went to Africa - not necessarily to Cape Verde - so as to earn a living, at the age of 15, and was affected by a disease which is not made explicit anywhere. At the time he wrote the poem (1852), Evaristo d'Almeida had already lived twelve years in Cape Verde, which means he would then have been at least 27 . His birthdate can thus be placed no later than 1825, which makes the hypothesis of his death having occurred in the following century unlikely. Further to this, we only know that he served as a congressman between 1850 and 1852 . 
As regards the novel, we can say that it was written in the taste of the period, presenting at its centre a love triangle (or square) with a touch of incest: the slave João is in love with Maria, his owner, who is a half-breed and has been protecting him for a long time, having even taught him how to read; Luísa, also a slave in the service of Maria, loves João; when her father, Captain Cláudio Pimentel, was away in Guinea where he had been sent, Maria and her mother receive the visit of Lopes, a military man and an exiled absolutist - a miguelista - who soon falls in love with the young lady. Playing the role of villain, Lopes attempts, unsuccessfully, a military revolt, for which he obtained the slaves' support and during which he tries to kidnap Maria. In this he is opposed by João, who pays for his bravery with his life, earning at his final breath his lady's affection. Parallel to the main intrigue, secondary stories emerge, the most important of which concerns a mysterious black woman named Júlia, who appears on the island of Santo Antão we do not know how or from where, sometime later becoming known as a witch. As the intrigue develops, we realize that Júlia is a victim in more than one way: of her former slave condition, while in the hands of her owner, Jerónimo Pimentel, who raped her, generating a baby, Cláudio, who was later to be Maria's father; as the widow of the slave Luís, with whom she had another son, João, an event which gave rise to resentment and the administration of punishment by Pimentel, whom she, having meanwhile been freed, will later try in vain to kill; as a victim of the society of the island of Santiago, where at one time she goes seeking for revenge and where she is rejected by everybody; and, finally, as a victim of the only son she acknowledges, João, who cannot accept his mother's intention to seek revenge against Cláudio and Maria, thus causing Júlia to deplore the alienation that her offspring had been subjected to: "Oh! a educação pode em ti mais que a natureza: eles haviam de ensinar-te a odiar tua mãe!..."1 (Almeida, 1856: 174).

In spite of the novelistic structure and the obedience to the romantic taste of the time, the narrative of José Evaristo d'Almeida contains many interesting aspects, including from a political-ideological point of view. First, it presents a very plausible picture of the archipelago's social structure, depicting a process of biological (Cláudio Pimentel, his wife and his daughter are half-breed) and cultural miscegenation (the narrator is careful to explain certain habits and forms of behaviour of the characters by referring to local customs). Second, it devotes considerable attention to aspects of African culture (expressions in Creole, the difference between the Creole used by men and by women, music and dance, forms of greeting, etc.). In addition, one finds there frequent criticisms of slavery (or, perhaps better, of its abuses) and European prejudice, although the narrator occasionally reveals a similar ethnocentric attitude. Let us look at just one example, related precisely to the song: "mas a música! a música era infernal! Sem cadencia, sem harmonia e sem gosto, julgaríeis ter na frente a copia viva do quadro de Hoghar «o músico desperado.»"2 (Almeida, 1856: 86)

\footnotetext{
1 "Oh! education prevails in you over nature: they had to teach you to hate your mother!..." (Here and elsewhere the translation is my own.)

2 "but the music! the music was infernal! Without cadence, without harmony and without taste, you would think you had before you the live copy of Hoghar's picture "The enraged musician.»"
} 


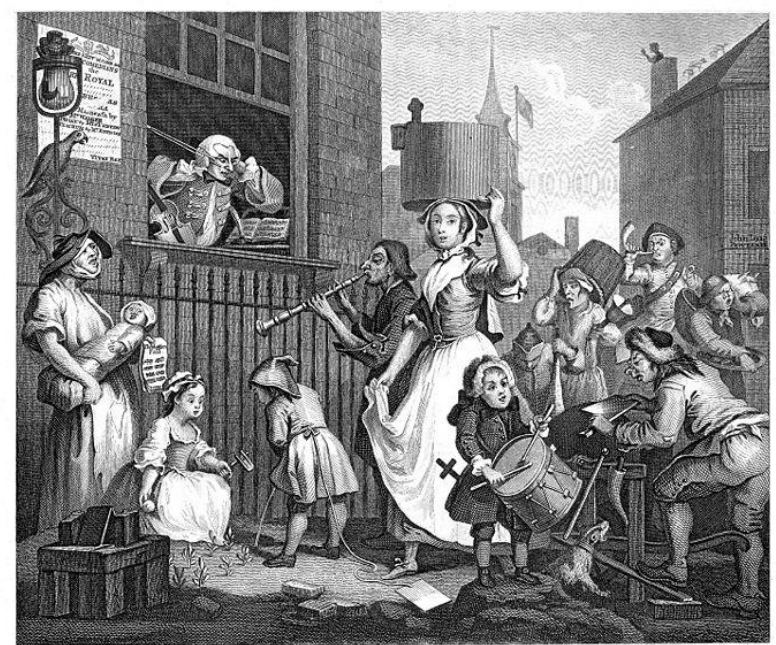

Source: https://en.wikipedia.org/wiki/The_Enraged_Musician\#/media/File:Enraged_musician.jpg

William Hogarth (1697-1764) was an English painter and engraver, and the engraving in question, The Enraged Musician, dates from 1741 and shows a violinist desperate at being unable to concentrate due to the noise coming from the street through the window. With this allusion the narrator's idea of music is made clear, as is the fact that African music did not fit his definition.

Let us return to the listing of the most important aspects of the novel, as mention should be made to the attribution of the role of protagonist to a slave, even though this slave wears, to use Fanon's phrase, a white mask. There are moments, however, when João adopts an attitude or a speech that signals a desire for change. Note the passage in which he declares that he felt a "prazer indefinível" 3 reading the "história da revolta dos negros na ilha de São Domingos"4 (Almeida, 1856: 14). This is certainly, as suggested by Cláudia Almeida (2009: maxime 79 et seq.), a reference to the reading of Victor Hugo's Bug-Jargal, the first printed version of which appeared in 1820, and to Haiti's revolution and independence. Although this dream of João as a liberating hero has no sequence, we cannot deny the importance of the hint that something like it could happen in Cape Verde. As a matter of fact, the slave several times speaks out against slavery, though in private (in front of Luísa) and in specific circumstances (after a heartbreak). Here is an instance: “- Maldição! oh! maldição sobre os brancos que primeiro vieram devassar nossos climas; que chamaram selvagens a nossos costumes; e que - despertando a ambição em nossos pais - os levaram a sacrificar seus filhos à posse de vis ouropéis!"5 (Almeida, 1856: 56)

In spite of what has just been said, it is nonetheless possible to argue in the opposite direction, maintaining that this is only a love story, after the romantic style, whose protagonist is more a slave of love than a slave in fact, and which ends with the death of the black man. Be that as it may, we must put the question into

\footnotetext{
3 "indefinable pleasure".

4 "story of the black revolt on the island of Santo Domingo".

5 "- Damnation! oh! a curse upon the whites who first came to invade our climates; who called our customs savage; and who - awakening ambition in our parents - led them to sacrifice their children to the possession of vile pinchbeck!"
} 
context, noting, for example, that if it is true that we are very far from The Interesting Narrative of the Life of Olaudah Equiano, or Gustavus Vassa, issued in 1789, it is also true that, by the time Evaristo d'Almeida published his novel, the theme of the black man and the slave was still in its beginnings in Portuguese-language literatures (note, for example, that Bernardo Guimarães' A escrava Isaura appeared only in 1875).

Another aspect to bear in mind is the fact that (at least partially) the background of $\mathbf{O}$ escravo is historical, based as it was on two events recorded by Sena Barcelos (1910): the rebellion, on the night of $21^{\text {st }}$ March 1835, of a battalion that had landed on $26^{\text {th }}$ February in Praia (this was the 21 $1^{\text {st }}$ Battalion of D. Miguel's Infantry, mostly composed of Azoreans from São Miguel (Barcelos, 1910: 53 et seq.)); and the rebellion, on the night of $6^{\text {th }}$ December of that same year, of a group of slaves who attempted to seize the village (Barcelos, 1910: 121 et seq.). The combination of the two events is fictional, as is, contradictory though it may seem at a first glance, the emptying of its historical density and its meaning: according to the ideology of the novel, both episodes are due to the action of evil beings (Lopes and Júlia), who came from the outside to try to disturb the island's idyll. In effect, rather than a miguelista who tries to reverse defeat, Lopes is presented above all as the white man from the metropolis, driven by greed and concupiscence. Similarly, Júlia is less the representative of the victims of slavery and of the system's inhumanity, and more the madwoman who acts only for revenge.

The distinctiveness of Manso's film resides precisely in the acknowledgement of the historical density that underlies the novel, which implied, as we shall see, a veritable recreation of the text. But before we reflect about the film, let us give a brief introduction to the filmmaker.

Francisco Manso (b. 1949) has a long film career as a screenwriter, producer and director, especially in the field of documentary filmmaking, with works such as Terra Nova (1983) or Memórias de um rio: Avieiros, nómadas do Tejo (2004); but also as the author of films about episodes and figures of the Portuguese history, such as Assalto ao Santa Maria (2009) or Aristides de Sousa Mendes: o Cônsul de Bordéus (2011); and in adapting to film some Cape Verdean novels, such as $O$ testamento do Sr. Nepumoceno da Silva Araújo (1997), A ilha dos escravos (2008) and Os dois irmãos (2018), the first and the last of which based on Germano Almeida's works. The second film, which interests us most here, had as its scriptwriter António Torrado, who did not exactly adapt the novel by Evaristo d'Almeida: as stated at the end of the film, this was only inspired by $\mathbf{0}$ escravo, mention also being made of the fact that the book was based on historical events of the first half of the $19^{\text {th }}$ century.

The first major difference between the two works lies in the title, which was changed from $\mathbf{O}$ escravo to $\mathbf{A}$ ilha dos escravos. This change, in addition to indicating a loss of relevance on the part of João, the slave, suggests that the space came to be represented as associated with slavery, which therefore became the central argument of the film, in an effort at an aesthetic and ideological updating of the novel. While still recounting a love story and a political-familial intrigue (now a little more complex, due to the modification of the figure of Lopes), the film has as its main focus a theme quite uncommon in Portuguese cinematography, something which is particularly odd if we consider that Portugal was one of the driving forces of modern large-scale slavery. This circumstance, associated with the natural difficulties inherent to a historical film, poses a considerable risk, both from the narrative point of view, and at a historical and ideological level. 
The title can also be interpreted as an allusion to the one-act comedy by Marivaux, L'île des esclaves, dated 1725. The play tells the story of four survivors of a shipwreck, who arrive at an island whose laws compelled master and servants to change roles. It is only after proving that they are able to adapt to a new social order that the characters are allowed to resume the journey. Manso's film is not a comedy nor does it present the utopian features of Marivaux's play. In spite of this, in the film, at moments, social roles are also inverted: we can see it in one of the initial scenes which seems to represent a black carnival party; and that is also the case of the scene in which the slave João beats Lopes at draughts.

Going back to the comparison between the book and the film, it can be said that the most immediate consequence of the choice of slavery as a central theme lies in the transformation of some characters, the most important being those of Tio Tesoura and Júlia (now often referred to as Mãe Júlia), who in the novel were secondary figures and in the film take on a relatively important role as anti-slavery leaders. The former, who was referred to in the book as a deportee running a tavern where the rebellious soldiers met, is presented in the film as an emancipated slave, who had come from the Brazilian mines in search of his African roots. Member of the Brotherhood of the Rosary, he seeks to gather means for the enfranchisement of those like him, dreaming of a revolution that would definitively put an end to slavery. Júlia, in spite of maintaining the characteristics of a sorceress-healer, is now more respected and feared than marginalized, a circumstance which explains her imprisonment by the authorities and her subsequent release by the black population. Clearly - not least because both roles are played by Brazilian actors (Milton Gonçalves and Zezé Mota, respectively) - this framework enables us to look at the question of slavery from a more global point of view that even reaches beyond the Portuguese sphere. It should be noted that a significant number of Brotherhoods of Our Lady of the Rosary were composed of "homens pretos" ["black men"], not only in Brazil but also in Cape Verde and other places, and that they operated as assistance and solidarity institutions, as well as means of identity affirmation and resistance. The island referred to in the film's title is a kind of synecdoche of a world marked by racial division, in which death or flight are the only solutions: Tesoura is shot; Júlia is buried (possibly alive) after the cave where she lives is blown up by governmental troops; only the slaves who had fled from a shipwrecked slave ship with a French flag embark as free men when returning to their lands. The (deceptive) suggestion that Lopes had made to Tesoura is therefore left unfulfilled: Cape Verde did not teach the world a lesson by abolishing slavery, especially since this would contradict history and because other countries had already taken that step. The tragic outcome of Evaristo d'Almeida's book is thus kept, although the tone is no longer one of resignation.

Be that as it may, there is a gap of a century and a half separating the two works - the distance from slavery to other racial struggles, the distance from a colonial to a post-colonial context - and there is the distance that goes from literature to cinema, the overcoming of which implied in this case an intersemiotic transposition that, legitimately, privileged recreation. If the final outcome, at least as regards reception of the film, was not brilliant, this was probably not the result of a lost translation, but rather of our unwillingness to confront ourselves with our past as slaver-holders. 


\section{Referências}

Almeida, Cláudia Bernardete Veiga de (2009). “0 escravo”: Entre a identidade caboverdiana e a literatura européia. MA in Comparative Studies of Portugueselanguage Literatures. São Paulo: FFLCH da USP.

Almeida, José Evaristo de (1852). Epístola a ${ }^{* * *}$. Lisbon: Imprensa Nacional.

Almeida, José Evaristo de (1856). O Escravo. Lisbon: Typographia de G. M. Martins.

Almeida, José Evaristo de (1989). 0 Escravo. Linda-a-Velha: ALAC.

Barcelos, Cristiano José de Sena (1910). Subsídios para a historia de Cabo Verde e Guiné. Memoria apresentada à Academia Real das Sciencias de Lisboa. Part IV. Lisbon: Typographia da Academia.

Lopes, Alberto Francisco Mendes (2010). Uma leitura do romance “0 escravo", de José Evaristo d'Almeida. MA in Literary, Cultural and Interarts Studies. Oporto: FLUP.

Manso, Francisco (Director) (2008). A ilha dos escravos. DVD. Lisbon: Costa do Castelo Filmes.

Marivaux, Pierre Carlet de Chamblain de (2000). L'île des esclaves. Edited with a preface and notes by Henri Coulet. [Paris]: Gallimard.

Pires, Maria do Carmo Martins (2008). "Narrações e recepções em 0 Testamento do Sr. Nepomoceno, romance de Germano Almeida e filme de Francisco Manso". In Diálogos lusófonos: literatura e cinema. Edited by Annabela Dinis Branco de Oliveira et al. Vila Real: UTAD, Centro de Estudos em Letras.

Sousa, Sérgio Paulo Guimarães de (2001). Relações intersemióticas entre o Cinema e a Literatura: a adaptação cinematográfica e a recepção literária do cinema. Braga: Universidade do Minho, Centro de Estudos Humanísticos.

Reginaldo, Lucilene (2011). Os rosários dos angolas: irmandades de africanos e crioulos na Bahia setecentista. São Paulo: Alameda Casa Editorial.

Topa, Francisco (2013). Para aquém de "O escravo": os poemas de José Evaristo d'Almeida. REVELL - Revista de Estudos Literários da U. Estadual de Mato Grosso do Sul. Campo Grande. ISSN: 2179-4456. II: 7 (2nd semester), pp. 62-77. 
TOPA, F. Lost in translation? from o escravo to a ilha dos escravos. Macabéa - Revista Eletrônica do Netlli, Crato, v. 10, n. 1, 2021, p. 481-488.

\section{O Autor}

FRANCISCO TOPA é professor Associado do Departamento de Estudos Românicos da Faculdade de Letras da Universidade do Porto, lecionando nas áreas de Literatura e Cultura Brasileiras, Crítica Textual, Literaturas Africanas de Língua Portuguesa e Literaturas Orais e Marginais. Doutorou-se em Literatura, em 2000, na mesma Faculdade, com uma tese sobre o poeta barroco Gregório de Matos. 